\title{
Analisis Inflasi Melalui Vektor Autoregresi Berganda (VAB) dengan Lima Variabel Informasi
}

\author{
Miftahuddin $^{\dagger}$
}

\begin{abstract}
Abstrak
Penelitian ini dilakukan untuk menganalisa dan menetapkan perkiraan inflasi karena adanya perbedaan perkiraan inflasi yang dikeluarkan lembaga pemerintah (Bank Indonesia) dan lembaga non-pemerintah. Berkaitan kelengkapan data dan waktu kajian, diawali dengan perkiraan angka inflasi Kota Banda Aceh bulan Mei 2008 dengan meneliti angka Indeks Harga Konsumen (IHK) dan variabel informasi yang diharapkan dapat membantu memperkirakan angka inflasi. Variabel informasi yaitu inflasi inti, aktiva bank, suku bunga SBI dan kurs rupiah terhadap dollar AS. Untuk mendapatkan model dilakukan dengan pendekatan VAB menggunakan software EViews 4.1. Dari hasil proyeksi inflasi model IHK dengan variabel informasi inflasi inti memberikan hasil terbaik karena memiliki nilai RMSE (Root Mean Square Error) terkecil yaitu sebesar 3.173 dan nilai Adjusted $R^{2}$ terbesar yaitu sebesar 0.988 diantara model-model lain yang diperoleh.

Dari model di atas diperoleh nilai proyeksi inflasi kota Banda Aceh bulan Mei 2008 yaitu sebesar 3.97\%, tetapi hasil proyeksi menyimpang dari nilai inflasi sebenarnya yang dikeluarkan oleh BPS kota Banda Aceh yaitu sebesar 3.78\%. Penyimpangan ini terjadi karena kenaikan harga BBM sehingga menyebabkan harga barang dan jasa juga naik. Melalui hasil perkiraan inflasi kota Banda Aceh tersebut dapat diestimasikan inflasi untuk kota/kabupaten lain di provinsi NAD. Dengan menggunakan asumsi yang sama (penggunaan variabel informasi, ada konstatnta dalam model, kenaikan harga BBM) dan dengan kisaran toleransi signifikan pada $\alpha=$ $1 \%$ - 5\%, maka diperoleh angka inflasi sebesar $4.0097 \%-4.1685 \%$ untuk kota/kabupaten lain di provinsi NAD pada bulan yang sama. Sedangkan prediksi untuk tahun mendatang angka inflasi masih pada kisaran tersebut bila tidak ada perubahan-perubahan asumsi.
\end{abstract}

Kata Kunci : Inflasi, VAB, IHK, RMSE, Adjusted $R^{2}$.

\section{Pendahuluan}

Bank Indonesia mempunyai satu tujuan tunggal yakni mencapai dan menjaga kestabilan nilai rupiah. Hal ini mengandung dua aspek yakni : (1). kestabilan nilai mata uang rupiah terhadap barang dan jasa yang tercermin pada laju inflasi; dan (2). kestabilan nilai mata uang rupiah terhadap mata uang negara lain yang tercermin pada perkembangan nilai tukar.

Inflasi merupakan fenomena moneter yang selalu meresahkan dan mempengaruhi stabilitas ekonomi suatu negara. Kenaikan harga dari satu atau dua barang saja tidak disebut inflasi, kecuali bila kenaikan tersebut meluas pada sebagian besar dari harga barang-barang lain dan adanya kecenderungan menaik secara terus-menerus. Kenaikan harga-harga, misalnya karena musiman, menjelang hari-hari besar, atau yang terjadi sekali saja tidak disebut inflasi dan tidak memerlukan kebijakan khusus untuk menanggulanginya.

\footnotetext{
${ }^{\dagger}$ Jurusan Matematika FMIPA Universitas Syiah Kuala Nangroe Aceh Darussalam
} 


\section{Miftahuddin}

Fluktuasi harga secara terus-menerus ini membawa dampak negatif bagi perekonomian di Kota Banda Aceh. Pada inflasi bulanan untuk Januari, Februari, Maret 2006 masing-masing sebesar $2.28 \%, 1.95 \%$, dan $-2.91 \%$. Hal ini dipengaruhi oleh pelaksanaan musim panen pada beberapa daerah dan mulai berproduksinya lahan-lahan pertanian yang dahulu rusak akibat tsunami dan semakin baiknya lalu lintas barang dan jasa ke Kota Banda Aceh, yang merupakan sentral dari kegiatan rehabilitasi dan rekontruksi Aceh. Sebelumnya laju inflasi naik pada bulan Oktober 2005 sebesar 12.45\% yang disebabkan oleh kenaikan Bahan Bakar Minyak atau BBM (BPS, 2004-2008).

Laju inflasi dalam arti sempit adalah meningkatkan tingkat harga barang atau jasa kebutuhan masyarakat secara rata-rata. Inflasi tinggi menunjukkan terjadi kenaikan harga ratarata barang/jasa kebutuhan cukup tinggi. Hal ini berarti terjadi penurunan kemampuan/daya beli uang untuk memperoleh barang/jasa. Laju inflasi biasanya dihitung dari persentase perubahan IHK pada suatu periode waktu.

Inflasi inti, suku bunga Sertifikat Bank Indonesia (SBI), dan aktiva bank merupakan faktor penting dalam menganalisis dan meramalkan inflasi, selain itu kurs rupiah terhadap dollar AS juga merupakan salah satu alternatif dalam pengendalian moneter khususnya berkaitan dengan pengendalian inflasi.

Perbedaan angka perkiraan inflasi yang dikeluarkan lembaga pemerintah dan nonpemerintah membuat pelaku ekonomi ragu dalam menetapkan ekspektasi inflasi. Dalam hal ini peneliti tertarik untuk memperkirakan angka inflasi di Kota Banda Aceh pada bulan Mei 2008 dengan pendekatan BVA, sebelumnya Badan Pusat Statistik (BPS) telah memperkirakan angka inflasi menggunakan formula Laspayres dengan modifikasi. BPS (2004) memperkenalkan formula Laspayres yang digunakan untuk menghitung inflasi setiap bulan sebagai berikut :

$$
I_{n}=\frac{\sum_{i=1}^{k} \frac{P_{n i}}{P_{(n-1)}} x P_{(n-1) i} Q_{o i}}{\sum_{i=1}^{k} P_{o i} Q_{o i}} \times 100
$$

dimana:

$$
\begin{array}{ll}
I_{n} & =\text { Inflasi bulan berjalan } \\
P_{n i} & =\text { Harga suatu jenis barang pada bulan berjalan } \\
P_{(n-1)} \quad= & \text { Harga suatu jenis barang pada bulan sebelumnya } \\
P_{(n-1) i} Q_{o i}= & \text { Nilai konsumsi suatu jenis barang pada bulan sebelumnya } \\
P_{o i} Q_{o i}= & \text { Nilai konsumsi suatu jenis barang pada tahun dasar } \\
k & =\text { Jumlah jenis barang atau jasa yang tercakup dalam paket komoditi kota yang } \\
& \quad \text { bersangkutan }
\end{array}
$$

\section{Tinjauan Pustaka}

\subsection{Inflasi}

Menurut Khalwaty (2000), inflasi didefinisikan sebagai suatu keadaan dimana terjadi kenaikan harga-harga secara tajam yang berlangsung terus-menerus dalam jangka waktu cukup lama. Seiring dengan kenaikan harga-harga tersebut, nilai uang turun secara tajam pula sebanding dengan kenaikan harga-harga tersebut. 


\section{Miftahuddin}

Boediono (1992) menggolongkan inflasi berdasarkan 'parah tidaknya' menjadi:

1. Inflasi ringan $(\leq 10 \%$ setahun).

2. Inflasi sedang (antara $10 \%-30 \%$ setahun).

3. Inflasi berat (antara $30 \%-100 \%$ setahun).

4. Hiperinflasi ( $\geq 100 \%$ setahun).

Secara teoritis inflasi disebabkan oleh:

1. Permintaan masyarakat akan berbagai barang terlalu kuat (demand pull inflation). Inflasi ini terjadi karena adanya gejala naiknya permintaan secara umum, sehingga sesuai dengan hukum permintaan maka harga pun secara umum akan cenderung naik atau kenaikan permintaan agregat melebihi kenaikan penawaran agregat.

2. Kenaikan biaya usaha (cost push inflation). Inflasi ini disebabkan oleh kenaikan penawaran agregat yang melebihi permintaan agregat. Penyebab kelebihan penawaran ini dapat dijelaskan dengan adanya dorongan kenaikan biaya produksi, seperti kenaikan upah, harga bahan baku baik impor maupun domestik, ataupun kekuatan struktural.

Formula untuk memperoleh persentase perubahan laju inflasi setiap bulan/tahun :

$$
L I_{n}=\frac{I_{n}-I_{(n-1)}}{I_{(n-1)}} \times 100 \%
$$

dimana:

$$
\begin{aligned}
& L I_{n} \quad=\text { laju inflasi bulan berjalan/tahun berjalan } \\
& I_{n} \quad=\text { indeks harga konsumen bulan berjalan/tahun berjalan } \\
& I_{(n-1)} \quad=\text { indeks harga konsumen bulan/tahun sebelumnya }
\end{aligned}
$$

\subsection{Ekspektasi Inflasi}

Ekspektasi inflasi mengandung dualisme, pertama memandang ekspektasi dipengaruhi oleh perilaku inflasi dimasa lalu (backward looking), kedua dikenal sebagai ekspektasi rasional (bersifat forward looking). Kedua anggapan tersebut berlaku di Indonesia mengingat tidak semua masyarakat berperilaku rasional (Dariwardani,2005). Formulasi kedua pendekatan tersebut dapat dilihat pada persamaan berikut:

$$
\begin{aligned}
& \pi=\overbrace{\alpha_{1} \pi_{b w}^{e}+\alpha_{2} \pi_{f w}^{e}}^{\text {ExpectedInflation }}+\alpha_{3}\left(Y-Y^{*}\right)+\alpha_{4} e \\
& \text { MoneterInfluence }
\end{aligned}
$$

dimana:

$$
\begin{array}{ll}
\pi & =\text { Persamaan linier ekspektasi inflasi } \\
e & =\text { Residual } \text { error } \\
\pi_{b w}^{e} & =\text { Ekspektasi inflasi masa lalu } \\
\alpha_{1} & =\text { Koefisien dari ekspektasi inflasi masa lalu } \\
\pi_{f w}^{e} & =\text { Ekspektasi inflasi rasional } \\
\alpha_{2} & =\text { Koefisien dari ekspektasi inflasi rasional }
\end{array}
$$




\section{Miftahuddin}

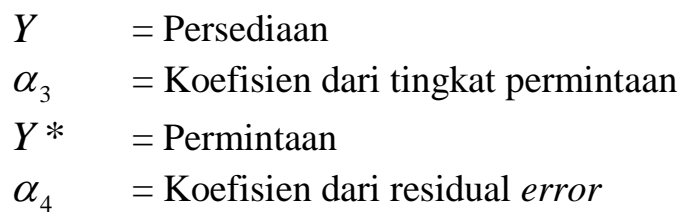

Berdasarkan persamaan tersebut teridentifikasi bahwa kemampuan bank sentral dalam pengendalian inflasi adalah melalui pengendalian tingkat permintaan $\left(Y-Y^{*}\right)$ dan pengendalian ekspektasi inflasi $\left(\pi_{f w}^{e}\right)$.

\subsection{Deflasi}

Secara sederhana yang disebut deflasi adalah kondisi ekonomi dimana jumlah kredit dan uang yang beredar berkurang. Ekonomi yang dijangkiti penyakit deflasi akan menunjukkan gejala harga-harga, gaji dan upah menurun, dimana cara menanggulanginya adalah dengan cara menurunkan tingkat suku bunga.

Dalam keadaan inflasi harga barang-barang dan jasa terus meningkat tajam, sedangkan keadaan deflasi harga barang-barang dan jasa terus menurun dengan tajam. Keduanya dapat mengancam dan merusak stabilitas perekonomian. Menurut Khalwaty (2000), deflasi adalah suatu keadaan ekonomi dimana harga barang-barang dan jasa mengalami penurunan dengan tujuan untuk menggairahkan produksi industri, kesempatan kerja dan meningkatkan nilai mata uang.

\subsection{Indeks Harga Konsumen (IHK)}

Harga konsumen adalah harga transaksi yang terjadi antara penjual (pedagang eceran) dan pembeli secara eceran dengan pembayaran tunai. Eceran yang dimaksud adalah membeli suatu barang atau jasa dengan menggunakan satuan kecil untuk dipakai/dikonsumsi.

Dalam pencatatan data harga konsumen perlu diketahui bahwa suatu komoditi dapat dijual dalam bentuk kemasan barang, misalnya dalam bentuk bungkus, botol, pak dan sebagainya. Demikian pula ada komoditi yang langsung dikenakan pajak. Data harga yang dicatat adalah benar-benar biasa dibayar, tanpa melihat bentuk kemasan, sudah dikenakan pajak atau belum dan sebagainya, sejauh satuannya adalah standar yang biasa dijual. Namun apabila suatu komoditi dibebani biaya tambahan lain seperti sumbangan, kupon dan sebagainya, maka biaya tersebut tidak perlu dimasukkan ke dalam harga barang/jasa tersebut.

IHK adalah mengukur rata-rata perubahan harga suatu paket komoditi dalam suatu kurun waktu tertentu atau antar waktu. IHK merupakan hasil pengolahan data harga konsumen di setiap kota. Pencacahan data meliputi jenis barang dan jasa, termasuk harga-harga makanan, pakaian, pemukiman, bahan bakar, transportasi, kesehatan, pendidikan dan komoditi lain yang menujang kehidupan sehari-hari yang di konsumsi oleh masyarakat. IHK sering digunakan untuk mengukur tingkat inflasi suatu daerah (BPS, 2004).

\subsection{Inflasi Inti}

Pengertian inflasi inti (core inflation or underlying inflation) dapat dilihat dari dua sudut pandang. Pertama inflasi inti adalah komponen inflasi yang cenderung 'menetap' atau persisten (persistent component) di dalam setiap pergerakan laju inflasi. Kedua inflasi inti sebagai kecenderungan perubahan harga-harga secara umum (generalized component). Konsep pertama mengisyaratkan perlunya pemisahan inflasi berdasarkan komponen yang persisten dan komponen yang temporer. Komponen yang persisten terkait dengan kondisi supply dan demand dalam 


\section{Miftahuddin}

perekonomian, sehingga secara teoritis dapat dipengaruhi oleh kebijakan moneter. Menurut Bank Indonesia (2003-2006), konsep kedua membedakan inflasi menjadi dua komponen yaitu inflasi inti yang terkait dengan ekspektasi inflasi dan kebijakan moneter, dan komponen perubahan harga relatif, terutama akibat gangguan-gangguan dari sisi supply (supply disturbances).

Inflasi inti yang dapat dipengaruhi atau dikendalikan oleh Bank Indonesia (BI). Penggunaan inflasi inti sebagai sasaran opersional dikarenakan inflasi inti dapat memberikan signal yang tepat dalam memformulasikan kebijakan moneter. Sebagai contoh, dalam hal terjadi gangguan permintaan (demand shock) yang mengakibatkan inflasi tinggi, respon bank sentral akan mengetatkan uang beredar sehingga tingkat inflasi dapat ditekan. Disamping itu, kebijakan tersebut dapat juga untuk menyesuaikan kembali pertumbuhan ekonomi pada tingkat yang sesuai dengan kapasitas perekonomian. Sebaliknya, jika inflasi meningkat karena terjadinya gangguan penurunan di sisi penawaran (supply side), misalnya kenaikan harga makanan karena musim kering maka kebijakan uang ketat justru dapat memperburuk tingkat harga dan pertumbuhan ekonomi. Respon yang dapat dilakukan oleh bank sentral adalah kebijakan melonggarkan likuiditas perekonomian justru diperlukan untuk menstimulir peningkatan penawaran.

\subsection{Aktiva Bank}

BI menggambarkan perkembangan kegiatan usaha perbankan yang diukur dengan aktiva yang dirinci menurut kelompok bank di Propinsi NAD. Pengertian aktiva bank adalah harta milik bank yang dikelola oleh bank yang bersangkutan untuk melaksanakan kegiatan usahanya dalam dunia perbankan. Penyajian data aktiva dimaksudkan terbagi menurut kelompok bank dan daerah tingkat II. Data aktiva bank yang dipakai dalam penelitian ini adalah aktiva bank menurut daerah tingkat II.

\subsection{Suku Bunga dan Sertifikat Bank Indonesia (SBI)}

SBI adalah surat berharga yang dikeluarkan oleh $\underline{B I}$ sebagai pengakuan utang berjangka waktu pendek (1-3 bulan) dengan sistem diskonto/bunga. SBI merupakan salah satu mekanisme yang digunakan Bank Indonesia untuk mengontrol kestabilan nilai Rupiah. Dengan menjual SBI, BI dapat menyerap kelebihan uang primer yang beredar. Tingkat suku bunga yang berlaku pada setiap penjualan SBI ditentukan oleh mekanisme pasar berdasarkan sistem lelang. BI menggunakan mekanisme "BI rate" (suku bunga BI), yaitu BI mengumumkan target suku bunga SBI yang diinginkan BI untuk pelelangan pada masa periode tertentu. BI rate ini kemudian yang digunakan sebagai acuan para pelaku pasar dalam mengikuti pelelangan.

Dalam inflation targeting framework, mekanisme transmisi kebijakan moneter berjalan melalui pembentukan ekspektasi pelaku ekonomi, dimana kebijakan moneter tersebut antara lain tercermin pada tingkat suku bunga dan SBI. Penggunaan suku bunga sebagai target operasional dimaksudkan untuk mempengaruhi likuiditas di pasar uang antar bank jangka pendek melalui seperangkat instrumen yang dimilikinya. Peningkatan suku bunga jangka pendek akan mengakibatkan peningkatan suku bunga yang lebih panjang, yaitu suku bunga deposito dan suku bunga kredit.

\subsection{Nilai Tukar (Kurs)}

Penentuan kurs valuta asing (valas) merupakan hal yang penting bagi pelaku bursa valas, karena kurs valas sangat mempengaruhi jumlah biaya yang harus dikeluarkan serta besarnya manfaat (keuntungan) yang akan diperoleh dalam transaksi barang, jasa dan surat berharga yang berlangsung di bursa valas. Fluktuasi kurs valas dipengaruhi oleh faktor fundamental, seperti 


\section{Miftahuddin}

jumlah uang beredar, tingkat inflasi, suku bunga, permintaan dan penawaran aset yang terjadi di beberapa negara yang memiliki hubungan ekonomi dan sistem keuangan internasional.

Dalam perekonomian terbuka kurs merupakan indikator harga yang relatif penting dalam perekonomian sehingga menjadi instrumen yang efektif dalam mencapai stabilitas harga. Dengan sistem managed floating system yang kini ditetapkan BI diharapkan stabilitas kurs rupiah terutama terhadap dollar Amerika dapat tercapai. Target nilai tukar (dengan menetapkan fixed exchange rate) merupakan salah satu alternatif dalam pengendalian moneter khususnya berkaitan dengan pengendalian inflasi.

\subsection{Uji Durbin-Watson (D-W)}

Uji D-W dalam menentukan ada atau tidaknya autokorelasi dalam regresi menggunakan pengujian terhadap nilai residu. Hasil dari statistik $d \mathrm{D}-\mathrm{W}$, kemudian dibandingkan dengan nilai $d$ tabel D-W. Dalam tabel $d$ itu dimuat dua nilai, yaitu nilai batas atas $\left(d_{U}\right)$ dan nilai batas bawah $\left(d_{L}\right)$ untuk berbagai nilai $\mathrm{N}$ (banyaknya observasi) dan $\mathrm{k}^{\prime}$ (banyaknya variabel bebas). Jumlah sampel minimal 15 sampai 100 observasi dan jumlah variabel bebas minimal 1 sampai 5 . Distribusi D-W adalah simetrik di sekitar 2, yaitu nilai tengahnya dengan selang kepercayaan yang melibatkan 5 wilayah seperti ditunjukkan pada gambar di bawah ini (Gujarati, 1995).

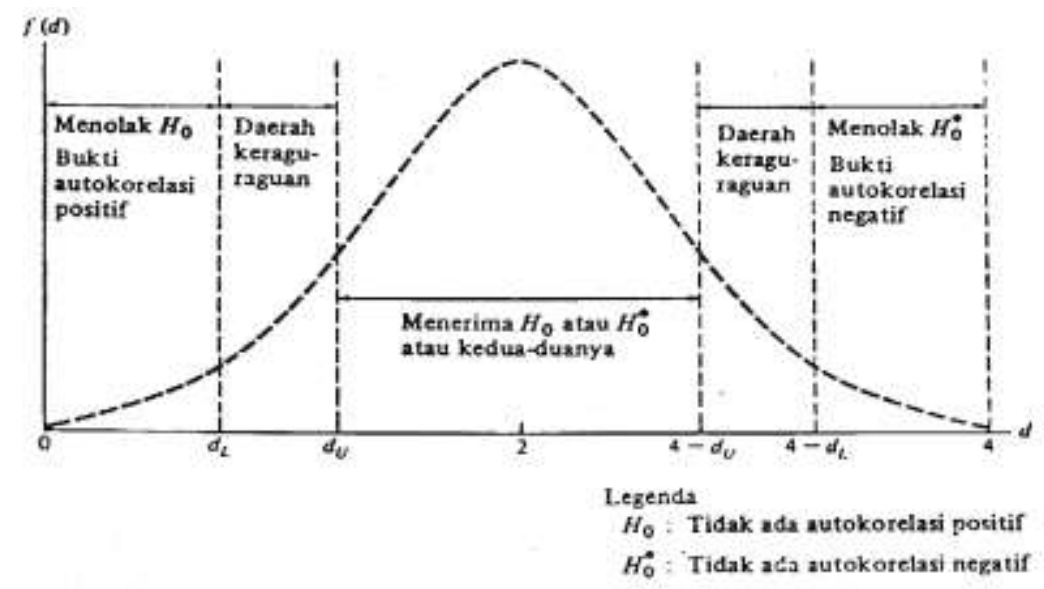

Gambar 2.1 Statistik d Durbin-Watson.

\subsection{Stasionaritas}

Kondisi stasioner ini digunakan untuk memperoleh model prediksi yang baik dapat ditunjukkan dengan persamaan matematis sebagaimana yang dikemukakan oleh Studentmund (2006) sebagai berikut :

$$
\begin{array}{ll}
\text { Rata-rata } & : E\left[Y_{t}\right]=\mu \\
\text { Variansi } & : \operatorname{Var}\left(Y_{t}\right)=E\left[\left(Y_{t}-\mu\right)^{2}\right]=\sigma^{2} \\
\text { Kovariansi } & : E\left[\left(Y_{t}-\mu\right)\left(Y_{t+k}-\mu\right)\right]=Y_{k}
\end{array}
$$

Pengujian kestasionaran menggunakan metode unit root test (uji akar unit), dengan menggunakan asumsi dasar yaitu: 


\section{Miftahuddin}

$$
\Delta Y_{t}=\alpha+\delta Y_{t-1}+\varepsilon_{t}
$$

dengan asumsi adanya konstanta dalam model regresi. Hipotesis yang diuji dalam uji akar unit ini adalah:

$H_{0}: \delta=0 \quad$ yang berarti data mengandung unit root (tidak stasioner)

$H_{1}: \delta \neq 0 \quad$ yang berarti data tidak mengandung unit root (stasioner)

Untuk menentukan keputusan pengujian apakah $H_{o}$ ditolak atau diterima maka dihitung terlebih dahulu nilai statistik dari uji ADF (Augmented Dickey-Fuller) yang dikenal sebagai $\tau$ statistic. Formulanya dapat dituliskan sebagai berikut: $\quad \tau=\frac{\delta}{\operatorname{Se}(\delta)}$ $\operatorname{Se}(\delta)$ adalah standar error dari koofisien $Y_{t-1}$ atau standar error dari $\delta$. Selanjutnya nilai $\tau$ statistic dibandingkan dengan nilai kritis Mackinnon. Jika nilainya lebih negatif dari nilai kritis Mackinnon maka $H_{0}$ ditolak atau dapat dikatakan data time series tersebut telah stasioner (tidak mengandung unit root).

\subsection{Kointegrasi}

Untuk menguji apakah dua peubah atau lebih memiliki hubungan jangka panjang dapat dilakukan uji kointegrasi. Apabila antara variabel dependent dan independent memiliki keterkaitan jangka panjang (cointegrated) maka kedua variabel tersebut layak digunakan untuk estimasi jangka panjang.

Ada beberapa tahap untuk dapat melakukan uji kointegrasi. Pertama-tama, variabelvariabel yang akan diuji harus lolos uji akar-akar unit terlebih dahulu. Kedua, variabel-variabel diregresi linier menggunakan persamaan : $x_{1 t}=a+b x_{2 t}+z_{t}$

$x_{1}$ dan $x_{2}$ adalah variabel yang akan diuji kointegrasi. Ketiga, error $\left(z_{t}\right)$ dari persamaan di atas didekati dengan nilai residual kemudian diuji stasionaritasnya menggunakan Augmented Dickey Fuller (Nugroho dkk, 2008). Jika di antara kedua variabel tersebut terkointegrasi, maka perubahan atas variabel $x_{1}$ akan dapat diprediksi melalui variabel $x_{2}$. Hal ini berarti jika variabel $x_{1}$ terkointegrasi dengan variabel $x_{2}$, akan terdapat hubungan jangka panjang antara kedua variabel.

\subsection{Metode Vektor Autoregresi (VA)}

Menurut Gujarati (1995), model VA merupakan model persamaan simultan dengan memodelkan setiap variabel endogen dalam sistem sebagai fungsi linier dari nilai lag atau selisih waktu (lagged value). Model VA bersifat fleksibel artinya tidak menutup kemungkinan penambahan variabel eksogen seperti dummy variabel asalkan peneliti telah memiliki asumsi mengenai nilai variabel eksogen tersebut di masa depan. Dalam penelitian ini model VA yang akan digunakan adalah model dengan dua peubah (berganda, bivariate). 


\section{Miftahuddin}

$$
\begin{aligned}
& y_{1 t}=a_{1}+\sum_{j=1}^{p} \Phi_{1 j} y_{1 t-j}+\sum_{j=1}^{p} \Phi_{1 j} y_{2 t-j}+u_{1 t} \\
& y_{2 t}=a_{2}+\sum_{j=1}^{p} \Phi_{2 j} y_{1 t-j}+\sum_{j=1}^{p} \Phi_{2 j} y_{2 t-j}+u_{2 t}
\end{aligned}
$$

dimana:

$$
\begin{aligned}
p & : \text { jumlah lag optimum; } \\
\Phi_{1 j}, \Phi_{2 j} & : \text { parameter autoregressive ke- } j \\
y_{1 t} & : \text { IHK kota Banda Aceh } ; \\
a_{1}, a_{2}: \text { konstanta } & \text { : variabel informasi, masing-masing yaitu inflasi inti, aktiva bank, suku bunga } \\
y_{2 t} & \text { SBI 1 bulan dan pertumbuhan kurs dollar AS } \\
y_{1 t-j} \quad: \text { IHK kota Banda Aceh ke-j; } & \text { variabel informasi ke- } j
\end{aligned}
$$

Asumsi yang harus dipenuhi model VA adalah:

1. $y_{1 t}$ dan $y_{2 t}$ keduanya stasioner.

2. $u_{1 t}$ dan $u_{2 t}$ merupakan gangguan (disturbances) yang bersifat white-noise dengan standar deviasi masing-masing $\sigma_{1}$ dan $\sigma_{2}$.

3. $\left\{u_{1 t}\right\}$ dan $\left\{u_{2 t}\right\}$ tidak saling berkorelasi atau individually serially uncorrelated.

Pemilihan panjang lag dalam estimasi model VA dilakukan secara arbitary. Lag minimum yang digunakan adalah 1 bulan dan lag maksimum yang digunakan adalah 12 bulan (1 tahun). Penentuan lag optimum dilakukan dengan melihat nilai Akaike Information Criterion (AIC). Panjang lag yang dipilih yaitu lag dari model VA yang memberikan nilai AIC terkecil.

\subsection{Pemilihan Model Terbaik}

Pemilihan model proyeksi terbaik dapat dilakukan dengan melihat daya prediksi dari masing-masing model. Daya prediksi diukur dengan seberapa jauh model dapat memberikan prediksi yang mendekati kebenarannya. Ukuran tersebut dapat dilihat dari nilai $R M S E$ terkecil atas model-model yang didapat (Anonimus, 2002). Di samping itu ukuran Adjusted $R^{2}$ dapat pula menjadi kriteria pemilihan model VAB.

\section{Metodologi Penelitian}

\subsection{Ruang Lingkup dan Sumber Data}

Data yang digunakan dalam penelitian ini adalah data sekunder yaitu data inflasi, IHK dan aktiva bank yang bersumber dari BPS; data inflasi inti yang berasal dari Bank Indonesia; data suku bunga SBI dan nilai tukar rupiah terhadap dollar AS yang berasal dari situs http://www.bi.go.id. Periode data yang digunakan adalah bulanan dari Januari 2003 sampai April 2008. Pada periode sampel tercakup dua tahun sebelum tsunami dan empat tahun setelah tsunami 


\section{Miftahuddin}

diharapkan mampu mewakili kondisi perekonomian Kota Banda Aceh yang semula stabil lalu mengalami lonjakan.

\subsection{Prosedur Penelitian}

Data yang diperoleh kemudian dianalisis melalui beberapa tahap:

1. Data diolah dengan bantuan software EViews 4.1 untuk melihat data stasioner atau tidak stasioner,

2. Kemudian uji kointegrasi untuk melihat data kointegrasi atau tidak kointegrasi.

3. Mendapatkan model VA dengan melihat nilai AIC terkecil,

4. Sedangkan untuk memperoleh model terbaik dengan melihat RMSE yang terkecil.

5. Melihat keseluruhan model diperoleh nilai proyeksi inflasi pada bulan Mei 2008 yang mendekati nilai inflasi yang sebenarnya. Prosedur pengujian D-W sebagai berikut:

1). Menentukan hipotesis

$H_{0}=$ tidak ada autokorelasi vs $H_{1}=$ ada autokorelasi positif/negative

2). Menentukan selang kepercayaan $\alpha$ dan nilai $d$ tabel Durbin-Watson

3). Menentukan kriteria pengujian

a. Untuk autokorelasi positif

$H_{0}$ diterima jika $d>d_{U}$ dan $H_{0}$ ditolak jika $d<d_{L}$

Tidak ada kesimpulan jika $d_{L}<d<d_{U}$

b. Untuk autokorelasi negatif

$H_{0}$ diterima jika $4-d>d_{U}$ dan $H_{0}$ ditolak jika $4-d>d_{L}$

Tidak ada kesimpulan jika $d_{L}<4-d<d_{U}$

4). Menentukan nilai statistik $d$ Durbin-Watson

5). Menyimpulkan tentang terima atau tolak $H_{0}$

\section{Pembahasan}

Perekonomian di Kota Banda Aceh tahun 2005 dan 2008 diawali dengan kenaikan harga BBM. BI mencatat bahwa tingginya inflasi tahun 2005 dan 2008 diakibatkan oleh naiknya harga BBM.

Tahun 2003 tercatat 7 kali mengalami deflasi, tahun 2004 tercatat 4 kali, tahun 2005, 2006, dan 2007 tercatat 3 kali mengalami deflasi. Deflasi tertinggi adalah sebesar $-2.91 \%$ pada bulan Maret 2006, hal ini dipengaruhi oleh semakin baiknya lalu lintas barang dan jasa ke Kota Banda Aceh dan mulai berproduksinya lahan-lahan pertanian yang dahulu rusak akibat tsunami. Keadaan deflasi ini secara umum disebabkan oleh turunnya harga barang dan jasa disejumlah pasar tradisional serta stabilnya permintaan masyarakatPlot dan forecast inflasi Kota Banda Aceh dapat dibuat grafik seperti diberikan di bawah ini. 


\section{Miftahuddin}

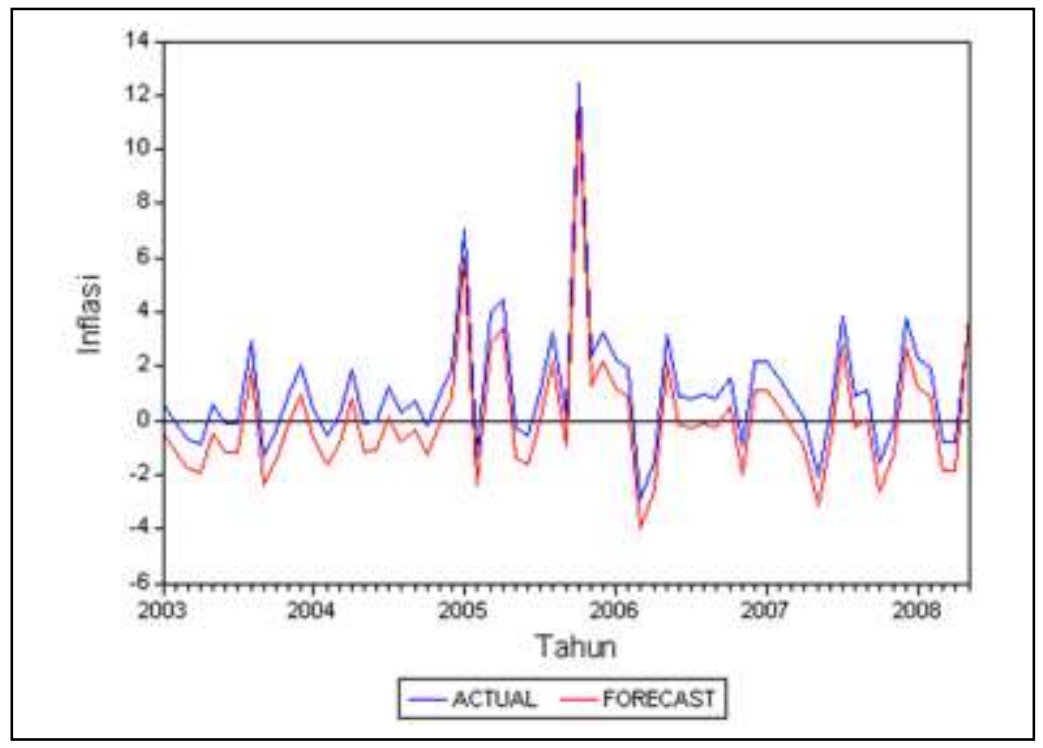

Gambar 4.1 Inflasi Kota Banda Aceh periode Januari 2003-April 2008

Isu dinaikan harga BBM terbukti dengan diumumkannya harga BBM pada bulan Maret 2005, dari tabel di atas inflasi bulan Maret 2005 tercatat sebesar 3.97\%. Inflasi tertinggi terjadi pada bulan Oktober 2005 sebesar 12.45\%, hal ini terjadi karena naiknya ekspektasi masyarakat akan inflasi akibat dinaikkannya harga BBM.

Uji stasionaritas dan uji kointegrasi dilakukan pada setiap deret yang digunakan dalam penelitian ini untuk memenuhi asumsi dalam model VAB.

\section{Uji Stasionaritas}

Pengujian stasionaritas dilakukan dengan menguji apakah data mengandung unit root (akar satuan). Dalam penelitian ini asumsi yang digunakan untuk uji unit root adalah adanya konstanta dalam pengujian regresinya.

Tabel 4.1 Ringkasan output hasil uji unit root (asumsi terdapat konstanta)

\begin{tabular}{|l|c|c|c|}
\hline \multicolumn{1}{|c|}{ Variabel } & $\begin{array}{c}\tau \text {-statistik dari } \\
\text { uji } A D F\end{array}$ & $\begin{array}{c}\text { Statistik } \\
\text { Durbin-Watson }\end{array}$ & $\begin{array}{c}\text { Konstanta } \\
\text { Regresi }\end{array}$ \\
\hline IHK** & $-7,786484$ & 1,994799 & 2,769335 \\
\hline Inflasi Inti** & $-6,202680$ & 1,969979 & 0,715834 \\
\hline Kurs** & $-6,967773$ & 1,973725 & 4,483702 \\
\hline SBI* & $-2,917159$ & 1,953051 & 0,472788 \\
\hline Aktiva Bank** & $-7,672943$ & 2,005075 & 149936,1 \\
\hline
\end{tabular}

Catatan : * Signifikan pada $\alpha=5 \%$; dan **Signifikan pada $\alpha=1 \%$

Berdasarkan nilai $\tau$-statistik dari uji ADF didapat bahwa variabel Inflasi Inti, dan SBI stasioner pada data dasar I(0), sementara variabel IHK, Kurs, dan Aktiva Bank stasioner pada data perbedaan pertama I(1). Untuk variabel IHK, Inflasi Inti, Kurs, dan Aktiva Bank stasioner pada tingkat kepercayaan 99\%, sementara untuk variabel SBI stasioner pada tingkat kepercayaan 95\%. Nilai statistik D-W yang didapat semua berada disekitar dua, yang menunjukkan bahwa pada sisaan dari regresi yang digunakan pada uji $A D F$ bebas dari masalah autokorelasi. 


\section{Miftahuddin}

\section{Uji Kointegrasi}

Hasil pengujian unit root pada residual regresi sederhana antara dua variabel yang diuji untuk melihat apakah memiliki hubungan kointegrasi atau tidak. Hasil penghitungan dirangkum pada tabel di bawah ini.

Tabel 4.2 Ringkasan output hasil uji unit root pada residual (asumsi terdapat konstanta)

\begin{tabular}{|l|c|c|c|}
\hline \multicolumn{1}{|c|}{ Pasangan Variabel } & $\begin{array}{c}\tau \text {-statistik dari } \\
\text { uji } A D F\end{array}$ & $\begin{array}{c}\text { Statistik } \\
\text { Durbin-Watson }\end{array}$ & $\begin{array}{c}\text { Konstanta } \\
\text { Regresi }\end{array}$ \\
\hline IHK dan Inflasi Inti** & -7.645727 & 2.000495 & 2.706092 \\
\hline IHK dan Kurs** & -9.097762 & 1.956714 & 1.711437 \\
\hline IHK dan SBI** & -8.843016 & 2.083997 & 3.582229 \\
\hline IHK dan Aktiva bank** & -9.969884 & 2.038530 & 0.734873 \\
\hline
\end{tabular}

Catatan: ** Signifikan pada $\alpha=1 \%$

Residual dari masing-masing pasangan variabel dilakukan uji $A D F$. Pada pengujian $A D F$ indikasi autokorelasi tidak terlihat karena nilai statistik D-W berada di sekitar dua. Hubungan kointegrasi antar variabel IHK dengan masing-masing variabel inflasi inti, kurs, SBI, dan aktiva bank signifikan pada tingkat kepercayaan 99\%. Dengan demikian dapat dikatakan bahwa inflasi memiliki hubungan jangka panjang (kointegrasi) dengan masing-masing variabel inflasi inti, kurs, SBI, dan aktiva bank, sehingga masing-masing variabel tersebut dapat menjadi variabel penentu dalam meramalkan inflasi kota Banda Aceh pada bulan Mei 2008.

\section{Model VAB}

Model VA inflasi akan diprediksi berdasarkan pergerakan IHK di masa lalu ditambah dengan informasi mengenai pergerakan variabel informasi di masa lalu. Beberapa hasil penghitungan khususnya untuk model IHK, dirangkum pada tabel di bawah ini sebelumnya data telah stasioner dan memiliki hubungan kointegrasi.

Tabel 4.3 Ringkasan penghitungan model inflasi pada bulan Mei 2008

\begin{tabular}{|l|c|c|c|c|c|c|c|}
\hline Pasangan variabel & AIC & $\mathrm{R}^{2}$ & $\begin{array}{c}\text { Adjusted } \\
\mathrm{R}^{2}\end{array}$ & F-stat & $\begin{array}{c}\text { П Mei } \\
2008\end{array}$ & RMSE & $\mathrm{D}-\mathrm{W}$ \\
\hline IHK dan Inflasi Inti** & 5.805 & 0.991 & 0.988 & 283.1751 & 3.97 & 3.173 & 1.926 \\
\hline IHK dan Kurs** & 6.249 & 0.982 & 0.979 & 482.6721 & 2.08 & 4.893 & 2.060 \\
\hline IHK dan SBI** & 6.325 & 0.981 & 0.978 & 336.9606 & 2.28 & 4.884 & 2.085 \\
\hline IHK dan Aktiva bank** & 6.405 & 0.977 & 0.976 & 611.5305 & 1.09 & 5.443 & 2.124 \\
\hline
\end{tabular}

Catatan: $\quad * * \quad$ Signifikan pada $\alpha=1 \%$

Berdasarkan Tabel 4.3, nilai AIC untuk IHK dengan variabel informasi inflasi inti terkecil pada lag 8, sementara IHK dengan kurs pada lag 3, IHK dengan SBI pada lag 4 dan IHK dengan aktiva bank pada lag 2. Sesuai dengan hasil tersebut maka diperoleh model VAB. Untuk peramalan inflasi bulan Mei 2008 digunakan model IHK saja.

Model-model yang terbentuk adalah:

1. Model IHK dengan variabel informasi inflasi inti

$\mathrm{IHK}=-0.158922 * \operatorname{IHK}(-1)-0.119925 * \operatorname{IHK}(-2)+0.118126 * \operatorname{IHK}(-3)+0.333073 * \operatorname{IHK}(-4)+$ $0.410392 * \operatorname{IHK}(5)+0.234516 * \operatorname{IHK}(-6)+0.185697 * \operatorname{IHK}(-7)+0.055365 * \operatorname{IHK}(-8)+$ 2.566506*inflasi_inti(-1)+ 


\section{Miftahuddin}

2.467324*inflasi_inti $(-2)+3.132469 *$ inflasi_inti $(-3)+2.657023 *$ inflasi_inti(-4) + $2.226699 *$ inflasi_inti $(-5)+1.312811 *$ inflasi_inti $(-6)+0.776763 *$ inflasi_inti $(-7)+$ 2.262856*inflasi_inti(-8) - 14.028597

2. Model IHK dengan variabel informasi kurs

$\mathrm{IHK}=0.449899 * \mathrm{IHK}(-1)+0.296548 * \operatorname{IHK}(-2)+0.244204 * \mathrm{IHK}(-3)+0.008770 *$ kurs $(-1)-$ $0.010156 *$ kurs $(-2)+0.007041 * \operatorname{kurs}(-3)-47.315269$

3. Model IHK dengan variabel informasi SBI

$\mathrm{IHK}=0.3029151 * \operatorname{IHK}(-1)+0.203279 * \operatorname{IHK}(-2)+0.271543 * \operatorname{IHK}(-3)+0.240057 * \operatorname{IHK}(-4)$ $+2.344116 * \operatorname{SBI}(-1)-0.345917 * \operatorname{SBI}(-2)+\quad 2.967139 * \operatorname{SBI}(-3)-4.742306 * \operatorname{SBI}(-$ 4) +0.090968

4. Model IHK dengan variabel informasi aktiva bank $\mathrm{IHK}=0.614770 * \operatorname{IHK}(-1)+0.355138 * \operatorname{IHK}(-2)+1.530596 \mathrm{e}-06 *$ aktiva_bank $(-1)-1.233230 \mathrm{e}-$ 06*aktiva_bank $(-2)+3.875811$

Sesuai Tabel 4.3 nilai F-statistik didapat bahwa model VAB signifikan dalam menjelaskan pergerakan inflasi pada tingkat kepercayaan 99\%. Pengujian residual menunjukkan bahwa tidak ditemukannya autokorelasi antar residual dimana nilai statistik D-W berada disekitar dua. Nilai koefisien determinan $\left(R^{2}\right)$ di atas 0.97 , yang berarti bahwa inflasi dapat dijelaskan oleh pergerakan IHK di masa lalu ditambah pergerakan variabel informasi di masa lalu.

Selanjutnya diperoleh pula forecast IHK dengan variabel informasi inflasi inti yang memiliki daya prediksi terbaik.

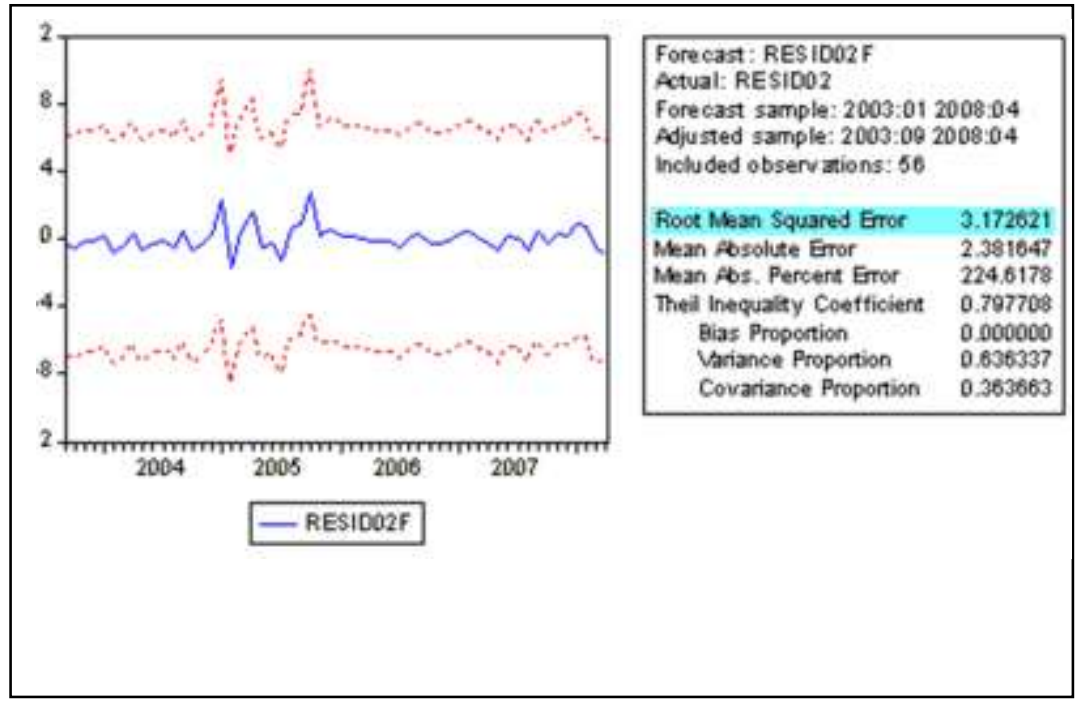

Gambar 4.2 Forecast IHK dengan variabel informasi inflasi inti

Sesuai Gambar 4.2 model IHK dengan variabel informasi inflasi inti memiliki daya prediksi terbaik karena memiliki nilai RMSE paling kecil, dan dari Tabel 4.3 nilai Adjusted $R^{2}$ terbesar di antara model-model yang lain. Dapat dikatakan bahwa inflasi inti merupakan variabel informasi yang paling baik guna meramalkan laju inflasi.

Berdasarkan hasil model VAB di atas diperoleh angka-angka proyeksi inflasi kota Banda Aceh untuk bulan Mei 2008. Walaupun hasil proyeksi inflasi menyimpang dari nilai inflasi sebenarnya sebesar $3.78 \%$, tapi proyeksi dengan variabel informasi inflasi inti memberikan hasil terbaik yaitu $3.97 \%$ dibandingkan dengan variabel informasi yang lain. 


\section{Miftahuddin}

Penyimpangan itu terjadi karena, akibat kenaikan berbagai jenis harga barang dan jasa. Secara umum rata-rata harga barang dan jasa mengalami bergerak naik selama bulan Mei karena kenaikan BBM. Hal ini mengakibatkan terjadinya kenaikan IHK dari $205.60 \%$ pada bulan April menjadi $213.37 \%$ pada mulai Mei. Akibat naiknya IHK bulan Mei, laju inflasi naik sebesar $3.78 \%$, dimana sebelumnya bulan April mengalami deflasi sebesar $-0.80 \%$. Inflasi bulan Mei dipicu oleh kenaikan beberapa komoditi bahan makanan sebesar $8.58 \%$, diikuti kelompok transportasi, komunikasi dan jasa keuangan sebesar $2.41 \%$, dan kelompok sandang sebesar $0.72 \%$, sedangkan untuk kelompok kesehatan mengalami inflasi sebesar $2.19 \%$, kelompok perumahan, air, listrik, gas dan bahan bakar $0.71 \%$.

Dari 4 model di atas, model IHK dengan variabel informasi inflasi inti yang memiliki daya prediksi terbaik adalah nilai AIC terkecil, nilai Adjusted $R^{2}$ terbesar, dan nilai $R M S E$ terkecil diantara 3 model tersebut.

\section{Kesimpulan}

Hasil dari pembahasan yang telah dilakukan dapat diambil kesimpulan :

1. Model yang diperoleh dari hasil penghitungan dengan software Eviews 4.1 adalah: $\mathrm{IHK}=-0.158922 * \operatorname{IHK}(-1)-0.119925 * \operatorname{IHK}(-2)+0.118126 * \operatorname{IHK}(-3)+0.333073 * \operatorname{IHK}(-4)+$ $0.410392 * \operatorname{IHK}(-5)+0.234516 * \operatorname{IHK}(-6)+0.185697 * \operatorname{IHK}(-7)+0.055365 * \operatorname{IHK}(-8)+$ 2.566506*inflasi_inti $(-1)+2.467324 *$ inflasi_inti $(-2)+3.132469 *$ inflasi_inti(-

$3)+2.657023 *$ inflasi_inti(-4) + 2.226699*inflasi_inti $(-5)+1.312811 *$ inflasi_inti(-

6) $+0.776763 *$ inflasi_inti $(-7)+2.262856 *$ inflasi_inti $(-8)-14.028597$

Dari model VAB diperoleh angka inflasi Kota Banda Aceh pada bulan Mei 2008 sebesar $3.97 \%$, sedangkan nilai inflasi sebenarnya sebesar 3.78\%. Penyimpangan itu terjadi karena, akibat kenaikan BBM pada bulan Mei 2008 sehingga harga barang dan jasa juga naik.

2. Variabel-variabel yang membantu memperkirakan angka inflasi pada bulan Mei 2008 adalah variabel inflasi inti, kurs rupiah terhadap dollar AS, suku bunga SBI, dan aktiva bank. Inflasi inti memiliki prediksi terbaik karena memiliki nilai RMSE paling kecil yaitu sebesar 3.173 dan nilai adjusted $R^{2}$ terbesar yaitu sebesar 0.988 di antara variabel-variabel yang lain. Hasil perhitungan inflasi ini tergolong inflasi ringan $(\leq 10 \%$ setahun).

3. Dengan kisaran toleransi signifikan pada $\alpha=1 \%-5 \%$, maka diperoleh angka inflasi sebesar $4.0097 \%$ - $4.1685 \%$ untuk kota/kabupaten lain di provinsi NAD pada bulan yang sama. Sedangkan prediksi untuk tahun mendatang angka inflasi masih pada kisaran tersebut bila tidak ada perubahan-perubahan asumsi, seperti krisis keuangan Amerika (September - Oktober 2008), yang menyebabkan krisis ekonomi dunia.

\section{Daftar Pustaka}

1. Anonimus. 2002, EViews 4.1 User's Guide.

2. Badan Pusat Statistik (BPS). 2004, Indeks Harga Konsumen, Badan Pusat Statistik, Nanggroe Aceh Darussalam.

3. Badan Pusat Statistik (BPS). 2004-2008, Laporan Perkembangan Pendapatan Daerah Provinsi Nanggroe Aceh Darussalam, Badan Pusat Statistik, NAD.

4. Bank Indonesia (BI). 2003-2006, Statistik Ekonomi dan Keuangan Indonesia, Bank Indonesia, Jakarta. 


\section{Miftahuddin}

5. Boediono.1992, Ekonomi Moneter, Edisi Ketiga, BPFE, Yogyakarta.

6. Dariwardani, M. I. 2005, Proyeksi Inflasi Indonesia Tahun 2005 Dengan Pendekatan Bivariate Vector Autoregressive, Jurnal Statistika, Ikatan Perstatistikan Indonesia, Jakarta.

7. Gujarati, D. 1995, Basic Econometrics, McGRAW. HILL, Singapore.

8. Khalwaty, T., 2000, Inflasi dan Solusinya, PT. Gramedia Pustaka Utama, Jakarta.

9. Lains, A., 2002. Ekonometrika Teori dan Aplikasi. Jilid I. LP3ES-UI. Jakarta

10. Makridakis, Spyros, 1999, Metode dan Aplikasi Peramalan jilid 1, Erlangga, Jakarta.

11. Nopirin. 1987, Ekonomi Moneter, BPFE, Yogyakarta.

12. Nugroho, R. H., dan Suryantini, A., Aplikasi Uji Akar-akar Unit dan Kointegrasi Dampak Inflasi terhadap Sektor Pertanian dengan Structural Break Sistem Nilai Tukar Mengambang bebas, http://syiefa.blogs.friendster.com/syiefa/2006/10/1, [25 Mei 2008].

13. Sarwoko. 2005, Dasar-Dasar Ekonometrika, Andi, Yogyakarta.

14. Statistik Ekonomi dan Keuangan Indonesia, http://www.bi.go.id/web/id/Statistik/, [25 Mei 2008].

15. Studentmund, A H. 2006, Using Econometrics A Practical Guide Fifth Edition, Pearson Education, Canada.

16. Supranto, J. 1983, Ekonometrik, LPFE-UI, Jakarta. 